産卵鶏に対する緑茶温湯抽出物給与の影響

\author{
山根哲夫 · 後藤尚也 - 高橋大三 · 武田英嗣 $\cdot$ 乙脇研仁 · 土田孝雄 \\ 日本配合飼料株式会社中央研究所，鹿島郡神栖町東深芝 4-2，茨城県 314-0103
}

\begin{abstract}
産卵鷂への緑茶温湯抽出物（WET）の給与が鶏の血清中成分, 産卵成績, 卵質, 卵成分及び卵白色に 及ぼす影響について検討した。市販産卵鶏用飼料（CP 18.3\%，ME $2,850 \mathrm{kcal} / \mathrm{kg}$ ）に，カテキンを $30 \%$ 含むように調製したWETを $0,0.17,0.33$ 及び $0.67 \%$ 添加した試験飼料を 53 週齢の白色レグホン種に 6 週間にわたって自由撖取させた。

その結果, WET 添加量が増すにつれて 1) 鶏の血清中脂質濃度は減少する傾向を示し, チオバルビ ッール酸反応物（TBARS）濃度は減少した。2）産卵率, 卵重, 飼料摂取量は低下した。3）卵殼強度, 卵款厚には变化が見られなかったが，八ウユニットはWET 0.17\%区及び $0.67 \%$ 区で無添加区と比較し $5 \sim 8 \%$ 向上した。4）卵黄の脂質含量はWET $0.17 \%$ 区で無添加区と比較し約 10\% 減少した。卵黄の TBARS 含量はWET $0.17 \%$ 区で約 $16 \%$ 減少した。卵黄の脂肪酸組成に变化は認められなかったが, 卵 黄脂質 $1 \mathrm{~g}$ 当たり TBARS 含量は減少する傾向が認められた。5）卵白の緑黄色が消失することが認めら れた。
\end{abstract}

(家禽会誌, $36: 31-37,1999)$

キーワード: 緑茶温湯抽出物, カテキン, 卵黄中脂質, チオバルビッール酸反応物, 卵白色

\section{緒}

言

緑茶は, カテキン類を主とするタンニンやカフェイン を主よするプリン塩基などの生理活性物質を多量に含む 特徴を有する。そのうち, (-)-エピカテキン, (-)-エピ

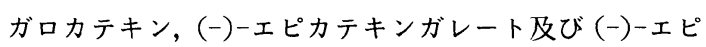
ガロカテキンガレートを主成分とするカテキン類は乾燥 した飲用の茶葉中に 10～14\%含まれ（池ヶ谷，1987）, 次に示す種々の機能を示すことで注目されている。すな わち, 抗酸化作用 (NANJO, et al., 1994 ; Yoshino, et al., 1994), 血糖上昇抑制作用（浅井ら，1987; HONDA and HARA, 1993 ; MATSUMOTO, et al., 1993), 血圧上昇抑制作 用 (原ら, 1987 ; 原・外岡, 1990), 血漿コレステロール 上昇抑制作用（福興ら，1986; MURAMATSU, et al., 1986), 抗腫瘍作用 (原ら, 1989 ; 浅井ら, 1990), 抗菌抗 ウイルス作用（戸田ら，1989，1990; MuKOYAMA, et al., 1991 ; NAKAYAMA, et al., 1993), 腸内細菌調整作用 (HARA, et al., 1995), 抗う蝕作用 (HATTORI, et al., 1990), 脱臭作用 (安田, 1992) 及び抗突然变異作用 (原, 1988）などである。カテキンの抗酸化機序はポリフェ ノール構造によるラジカル捕捉作用で説明され，松崎・ 原（1985）は緑茶から精製したカテキンのラードに対す る抗酸化力は, ブチルヒドロキシアニソール及び $\mathrm{DL}-\alpha-$ 1998 年 4 月 21 日受付 1998 年 7 月 24 日受理
トコフェロールより強いことを認めた。緑茶の生体内抗 酸化作用について, 大澤・並木（1982）はラット肝臓の ミクロソーム画分の脂質過酸化を酵素的に誘導し, 茶力 テキン類がその過酸化反応を抑制できるかを検討した結 果, エピガロカテキンガレート及びエピカテキンガレー

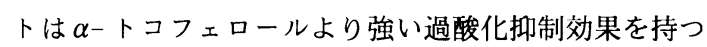
ことを明らかにした。

このように, 茶力テキンの機能は動物やヒトの健康に 資する点が多いが, 家畜, 家离に緑茶, あるいはカテキ ンを給与した場合の影響に関する報告は少なく, 以下の 数報が見られるのみである。すなわち, 佐野ら（1995, 1996）はブロイラー用飼料に茶葉または茶がらを $3 \%$ 混 合し給与した結果, 屠体の $\mathrm{K}$ 值の上昇が抑制され, 同時 に肉中の過酸化脂質含量の低下およびビタミン $\mathrm{A}$ 含量 とビタミン $\mathrm{E}$ 含量の増加が認められたことを報告した。 また, 池谷ら（1995）は産卵鷄用飼料に茶葉または茶が らを $5 \%$ 混合し給与した場合産卵率と卵款質の低下が見 られるが, $1 \%$ では生産性に影響がなく,また, 卵黄中の ビタミン E 含量が増加することを報告している。そこ で, 本試験では, カテキンを $30 \%$ 含むように調製した緑 茶温湯抽出物（Hot Water Extract of Tea, WET) を産 卵䊿飼料に添加, 給与し, 鶏の血清中成分, 産卵成績, 卵質及び卵成分に及ぼす影響について検討するための 2 つの試験をした。 


\section{実験材料及び方法}

試験 1 鶏の血清中成分, 産卵成績, 卵質及び卵黄中成 分に及ぼす飼料への WET 添加の影響

53 週齢の白色レグホン種産卵鶏（シェーバー 21） 160 羽を 40 羽ずっの 4 区に分け，次に示す試験飼料を 6 週 間自由摂取させた。すなわち, CP 18.3\%, ME 2,850 kcal/ $\mathrm{kg}$ の市販産卵鷂用飼料に，外割で WET をカテキン換 算量として $0,0.05,0.10$ 及び $0.20 \%$ となるようにそれ ぞれ $0,0.17,0.33$ 及び $0.67 \%$ の 4 水準添加した。

WET はポリフェノン G (三井農林(株)製 ; カテキン 含有量 30\%）を使用した。測定項目は生存率, 産卵率, 卵重, 飼料摂取量, 卵款強度, ハウュニット (HU), 血 清中脂質濃度, 血清中チオバルビッール酸反応物 （TBARS）濃度, 卵黄中粗脂肪, 卵黄中 TBARS 含量, 卵黄脂質 $1 \mathrm{~g}$ 中 TBARS 含量及び卵黄の脂肪酸組成とし た。生存率, 産卵率, 卵重及び飼料摄取量は飼料給与開 始後 6 週間の成績を用い, 卵款強度及び HU は給与後 6 週目の鶏卵 20 個を用いて测定した。血清中脂質濃度, 血 清中 TBARS 濃度は, 給与後 6 週目の鶏について各試験 区から 5 羽を無作為に取り出して採血した。得られた血 清は冷蔵保存し, 採血後 1 週間以内に分析に供した。卵 黄中粗脂肪, 卵黄中 TBARS 含量は飼料給与後 6 週目の 卵を各区 15 個採取し，その中から無作為に 5 個を取り 出し, その卵黄を分析に供した。卵黄の脂肪酸組成は各 区から 5 個ずつ採取した卵を割卵，卵黄を分取した後一 つにまとめて分析に供した。血清中脂質の定量は臨床検 查用試薬（アムコ(株)製モノパック総脂質）により，血 清中 TBARS 濃度の測定は YAGI（1976）の方法によっ た。卵黄の粗脂肪含量の定量と脂肪酸組成の分析は衛生 試験法（1990）の方法によった。卵黄中 TBARS の测定 は, 基本的に日本薬学会編衛生試験法（1990）に記載さ れた方法でのチオバルビッール酸（TBA）法によった が, 測定中の検体の酸化進行を妨げるために, 脂質画分 の抽出では暗可, 室温下で 12 時間浸漬したこと, TBA 試薬にブチルヒドロキシトルェンを $0.1 \%$ 添加したこよ (AsAKAWA and MATSUSHITA, 1980) の二点の変更を 行った。HUの测定は卵黄・卵白高測定器（富士平工業 (株)製）により行った。

試験 2 卵白色に及ぼす飼料への WET 添加の影響

34 週齢の褐色鵎（ボリスブラウン） 70 羽を 10 羽ずっ の 7 区に分け, 次に示す試験飼料を 8 週間自由攝取させ た。すなわち, CP 18.3\%, ME 2,850 kcal $/ \mathrm{kg}$ の市販産卵 鶏用飼料に, 外割で WETをカテキン換算量として 0 , $0.01,0.03,0.05,0.10,0.15$ 及び $0.20 \%$ となるようにそれ ぞれ $0,0.03,0.10,0.17,0.33,0.50$ 及び $0.67 \%$ の 7 水準添
加した。試験飼料給与後 8 週目の卵を採り, 各試験区か ら無作為に 5 個を取り出し, 以下の方法により卵白色を 測定した。

すなわち，WET 添加による卵白色の変化の程度は濃 厚卵白，水様性卵白共に同様であったので，卵白を金網 で濃厚卵白と水様性卵白とに分け，水様性卵白を $1 \mathrm{~cm}$ 角のセルにとり分光光度計（(株) 日立製作所製 U-2000 型）により，黄色色素 $\beta$-カロテンの吸収極大波長であ る $440 \mathrm{~nm}$ での吸光度を測定し, 卵白色とした。

なお，各測定值の統計妈理は DUNCAN（1955）の多重 範囲検定法により行った。

\section{結果及び考察}

\section{試験 1}

血清中脂質及び TBARS 濃度の測定結果を表 1 に示 した。脂質濃度は飼料中 WET 含量の増加につれて低下 する傾向が認められた。岩田ら（1987）は高血圧自然発 症ラットにウーロン茶の熱湯抽出液を給与した場合に血 漿中の中性脂肪が対照区に比較して低下したことを報告 しており，産卵鶏においてもラットと同様の結果を示す ことが考えられた。

TBARS 濃度は飼料中 WET 含量の増加につれて低下 し, WET 無添加区と $0.67 \%$ 区との間に差を認めた。

TBARS は脂質の過酸化の程度を示す指標として広く 用いられている。青柳ら（1997）は高温暴露のストレス 負荷によりヒナの血漿中の TBARS が増加することを 報告している。今回の試験は通常環境で飼育されたもの であるが，WET に含まれる抗酸化物質カテキンは鵎に おいて酸化にかかわるストレスを低減させる可能性を示 唆するものと考えられる。

産卵成績を表 2 に示した。WET 添加群の飼料攝取量 はWET 添加量が増すにつれて減少した。この原因が力 テキンの苦みによるものか，またはその他の成分による あのかは明らかではない。WET の添加率が増えるにつ れて産卵率と卵重が低下した。WET 0.67\%区において は，無添加区と比較して卵重の低下率は約 $2 \%$ であった ことに対し，産卵率の低下率は約 50\% と大きかった。 WET 添加の影響が卵重より産卵率に大きかった原因及 び産卵率の低下が飼料摄取量の減少のみによるものかは 不明である。

卵質の測定結果を表 3 に示した。WET 添加率が増す につれて HU が上昇し，0.17\%区及び 0.67\% 区と無添加 区の間に差が認められた。WET 給与と卵質の関係につ いてはこれまで報告がなく，この原因は不明であるが, WET の主な生理活性成分がカテキンであることから， カテキンの生体内抗酸化作用による可能性が考えられ 
表 1. 緑茶温湯抽出物が産卵䊿の血清中脂質およびチオバルビッール酸 反応物（TBARS）濃度に及ぼす影響

Table 1. Effects of hot water extract of tea (WET) on serum concentration of total lipid and thiobarbituric acid reactive substances (TBARS) of hens

\begin{tabular}{ccc}
\hline $\begin{array}{c}\text { 添加量 } \\
\text { WET } \\
(\%)\end{array}$ & $\begin{array}{c}\text { 血清中脂質濃度 } \\
\text { Total lipid concentration } \\
(\mathrm{mg} / \mathrm{d} l)\end{array}$ & $\begin{array}{c}\text { 血清中 TBARS 濃度 } \\
\text { TBARS concentration } \\
(\mathrm{nmol} / \mathrm{m} l)\end{array}$ \\
\hline 0 & $3,053 \pm 381$ & $11.8 \pm 2.61^{\mathrm{a}}$ \\
0.17 & $2,518 \pm 582$ & $9.8 \pm 2.06^{\mathrm{a}}$ \\
0.33 & $2,471 \pm 745$ & $10.6 \pm 2.01^{\mathrm{a}}$ \\
0.67 & $2,174 \pm 489$ & $8.6 \pm 1.64^{\mathrm{b}}$ \\
\hline
\end{tabular}

平均值士標準偏差.

Mean \pm SD for 5 hens.

区間において異符号間に $5 \%$ 水準の危険率で有意差あり.

Values within the same rows having different letters are significantly different $(\mathrm{P}<0.05)$.

表 2. 緑茶温湯抽出物が産卵鶏の産卵成績に及ぼす影響

Table 2. Effects of hot water extract of tea (WET) on laying performance

\begin{tabular}{|c|c|c|c|c|}
\hline WET (\%) & 0 & 0.17 & 0.33 & 0.67 \\
\hline 生 存 率 $(\%)$ & 100.0 & 100.0 & 100.0 & 92.5 \\
\hline $\begin{array}{l}\text { 産 卵 } \quad \text { 率 }(\%) \\
\text { Egg production rate }\end{array}$ & $79.9^{a}$ & $77.5^{\mathrm{a}}$ & $66.5^{\mathrm{a}}$ & $40.2^{\mathrm{b}}$ \\
\hline $\begin{array}{l}\text { 㧮 } \\
\text { Egg weight }\end{array}$ & $67.5^{\mathrm{a}}$ & $66.1^{\mathrm{b}}$ & $66.8^{\mathrm{ab}}$ & $66.2^{\mathrm{b}}$ \\
\hline 量（g/hen/day） & $53.9^{\mathrm{a}}$ & $51.3^{\mathrm{a}}$ & $44.5^{\mathrm{a}}$ & $26.6^{\mathrm{b}}$ \\
\hline $\begin{array}{l}\text { 飼 料 搷 取 量 (g/hen/day) } \\
\text { Feed intake }\end{array}$ & $122^{\mathrm{a}}$ & $118^{\mathrm{a}}$ & $109^{b}$ & $90^{c}$ \\
\hline $\begin{array}{l}\text { 飼 料 要 求 率 (Feed/egg) } \\
\text { Feed conversion ratio }\end{array}$ & $2.27^{\mathrm{b}}$ & $2.31^{\mathrm{b}}$ & $2.51^{\mathrm{b}}$ & $4.27^{\mathrm{a}}$ \\
\hline
\end{tabular}

区間において異符号間に $5 \%$ 水準の危険率で有意差あり.

Values within the same rows having different letters are significantly different $(\mathrm{P}<0.05)$.

る。卵殻強度，卵殻厚は変化が見られなかった。

池谷ら（1995）は産卵鷄用飼料に茶葉または茶がらを $5 \%$ 混合し給与したときに飼料摄取量, 産卵率が低下し たことを報告しており，これは本実験の結果と一致する が，卵殼強度と卵殻厚が低下したことでは本実験結果と 一致しない。彼らの報告における茶葉または茶がらの添 加量をカテキン含量で換算した場合, 総エピカテキン類 として茶葉 $5 \%$ 区では約 $0.6 \%$, 茶がら $5 \%$ 区では約 $0.4 \%$ となり，これは本実験の WET 最大添加区（0.67\% 区）における $0.2 \%$ に対して明らかに高い数值である。 卵款強度と卵殻厚において異なる結果が見られた主因は 飼料中に含まれる茶, 茶がら, またはカテキンの含量の
違いにあると思案されるが，同時に，本実験では茶葉の 温湯抽出物を用いたのに対し, 彼らは茶葉と茶がらを用 いていることから，茶葉に含まれる温湯不溶物が影響し た可能性も考えられる。

卵黄の粗脂肪及び TBARS 含量の測定結果を表 4 に 示した。卵黄の粗脂肪含量は飼料中の WET 添加量が増 えるにつれて減少し，その割合はWET 無添加区に比較 し $0.17 \%$ 区で約 $10 \%$ であった。これまで飼料によって 卵黄粗脂肪を減少させることができたという報告は見当 たらない。木村ら（1984）はウーロン茶に腸管での脂質 吸収抑制, 脂肪組織からの脂肪動員抑制及び末梢組織で の脂質利用促進の作用があることを推测し, 
表 3. 緑茶温湯抽出物が産卵鶏の卵質に及ぼす影響

Table 3. Effects of hot water extract of tea (WET) on egg qualities

\begin{tabular}{|c|c|c|c|c|}
\hline WET $(\%)$ & 0 & 0.17 & 0.33 & 0.67 \\
\hline $\begin{array}{l}\text { ハウユニット } \\
\text { Haugh Unit }\end{array}$ & $81.9 \pm 3.11^{\mathrm{c}}$ & $85.8 \pm 4.79^{\mathrm{ab}}$ & $83.0 \pm 7.84^{\mathrm{bc}}$ & $88.7 \pm 3.90^{\mathrm{a}}$ \\
\hline $\begin{array}{l}\text { 卵款強度 }\left(\mathrm{kg} / \mathrm{cm}^{2}\right) \\
\text { Egg shell strength }\end{array}$ & $2.74 \pm 0.84$ & $2.76 \pm 0.95$ & $2.55 \pm 0.83$ & $2.59 \pm 0.77$ \\
\hline $\begin{array}{l}\text { 㧮 殼 厚 }(\mathrm{mm}) \\
\text { Shell thickness }\end{array}$ & $0.376 \pm 0.019$ & $0.372 \pm 0.026$ & $0.368 \pm 0.040$ & $0.367 \pm 0.046$ \\
\hline $\begin{array}{l}\text { 卵黄 色（ロシュ，1993） } \\
\text { Yolk color fan score (Roche 1993) }\end{array}$ & $10.4 \quad \pm 0.59$ & $10.4 \pm 0.67$ & $10.5 \pm 0.89$ & $10.2 \pm 0.86$ \\
\hline
\end{tabular}

平均值土標準偏差.

Mean \pm SD for 20 eggs.

区間において異符号間に5\% 水準の危険率で有意差あり.

Values within the same rows having different letters are significantly different $(\mathrm{P}<0.05)$.

表 4. 緑茶温湯抽出物が産卵鶏の卵黄中粗脂肪, チオバルビッール酸反応物 （TBARS）含量に及ぼす影響

Table 4. Effects of hot water extract of tea (WET) on crude fat and thiobarbituric acid reactive substances (TBARS) contents in yolk

\begin{tabular}{|c|c|c|c|}
\hline $\begin{array}{l}\text { 添加量 } \\
\text { WET } \\
(\%)\end{array}$ & $\begin{array}{c}\text { 卵黄中粗脂肪含量 } \\
\text { Crude fat content } \\
(\%)\end{array}$ & \multicolumn{2}{|c|}{$\begin{array}{c}\text { 卵黄中 TBARS 含量 } \\
\text { TBARS content in yolk }\end{array}$} \\
\hline 0 & $37.3 \pm 2.22^{\mathrm{a}}$ & $64.9 \pm 2.59^{\mathrm{a}}$ & $174 \pm 13.1$ \\
\hline 0.17 & $33.6 \pm 1.77^{\mathrm{b}}$ & $54.7 \pm 4.14^{\mathrm{b}}$ & $163 \pm 20.9$ \\
\hline 0.33 & $34.3 \pm 0.82^{\mathrm{b}}$ & $52.4 \pm 3.08^{b}$ & $153 \pm 11.7$ \\
\hline 0.67 & $32.8 \pm 1.74^{\mathrm{b}}$ & $53.0 \pm 3.33^{\mathrm{b}}$ & $162 \pm 16.9$ \\
\hline
\end{tabular}

平均値士標準偏差.

Mean \pm SD for 5 eggs.

区間において異符号間に 5\% 水準の危険率で有意差あり.

Values within the same rows having different letters are significantly different ( $\mathrm{P}$ $<0.05)$.

MATsumoto et al. (1993) はラットにカテキンを添加し たパーム油含有飼料を給与したとき，飼料摂取量と体重 は変化しないが体脂肪割合が減少したこと，また，ラッ トに粗カテキンを与え, 30 分後にデンプン, スクロー ス，あるいはグルコースを経口投与したときに血糖値， 血中インスリン濃度が対照区で著しく上昇したのに対 し, 粗カテキン投与区では低い濃度に抑えられたことか ら，カテキンが体内で脂肪合成を抑制すると報告した。 今回卵黄の粗脂肪が減少した原因は WET 給与により血 清中の脂質が減少したことと合わせ，カテキンによる腸 管からの脂肪吸収阻害, あるいは体内での脂肪合成の抑 制があった可能性が示唆された。

WET 添加量が増すにつれて卵黄中の TBARS 含量が 減少した。カテキンがビタミン E やアスコルビン酸と同 様に活性酸素による酸素障害から生体を防御することは
よく知られているが, OKUDA et al. (1983) はラット肝ミ トコンドリア及びミクロソームにおける脂質過酸化に対 する各種タンニンの影響を調べた実験で, エピガロカテ キンガレートが $\alpha$-トコフェロールに比べ強い抑制作用 を持つことを明らかにし，またNAMIKI and OSAWA （1986）はラット肝ミクロソーム系及びウサギ赤血球 ゴースト系において， $\alpha$-トコフェロールやブチルヒド ロキシアニソールに比較し茶カテキン類が優れた脂質過 酸化抑制能を持つことを示した。佐野ら（1995，1996） はブロイラ一用飼料に茶葉または茶がらを $3 \%$ 混合し給 与したときに，ムネ肉中の過酸化脂質含量が低下したこ とを報告し，これは茶の抗酸化能によるものと考察して いる。本実験で卵黄の TBARS 含量が対照区より減った ことは, WET 中カテキンの生体内抗酸化作用が卵胞形 成中にも㗢いていることを示していると考えられる。 
表 5. 緑茶温湯抽出物が卵白色に及ぼす影響

Table 5. Effects of hot water extract of tea (WET) on color of egg white

\begin{tabular}{cc}
\hline \hline $\begin{array}{c}\text { 添加量 } \\
\text { WET } \\
(\%)\end{array}$ & $\begin{array}{c}\text { Color of egg white } \\
\text { (absorbance at 440nm) }\end{array}$ \\
\hline 0 & $0.201 \pm 0.008^{\mathrm{a}}$ \\
0.03 & $0.173 \pm 0.021^{\mathrm{ab}}$ \\
0.10 & $0.124 \pm 0.011^{\mathrm{b}}$ \\
0.17 & $0.106 \pm 0.019^{\mathrm{bc}}$ \\
0.33 & $0.087 \pm 0.005^{\mathrm{c}}$ \\
0.50 & $0.091 \pm 0.023^{\mathrm{c}}$ \\
0.67 & $0.082 \pm 0.020^{\mathrm{c}}$ \\
\hline
\end{tabular}

平均値士標準偏差.

Mean \pm SD for 5 eggs.

区間において異符号間に $5 \%$ 水準の危険率で有意差あ り.

Values within the same rows having different letters are significantly different $(\mathrm{P}<0.05)$.

また，卵黄脂質 $1 \mathrm{~g}$ あたりの TBARS 含量を計算する と, TBARS 含量は飼料中 WET 含量が増えるにつれて 低下する傾向が認められたことから，卵黄中の TBARS 含量の低下は粗脂肪含量の低下のみによるあのではない と考えられる。なお, 脂肪酸組成はWET の給与により 変化しなかった。

WET 添加量が増すにつれて飼料摂取量が急激に低下 し，これに伴って産卵率，卵重が低下した。血液成分や 卵質にも変化が見られたが，これらの結果に対する飼料 摄取量の影響は本試験からは明らかでない。

しかし，WET 無添加区と 0.17\%区との比較では，前 者の飼料摂取量 $122 \mathrm{~g}$ に対して後者は $118 \mathrm{~g}$ とほぼ同量 を摄取しているのに対して, 後者では血清中脂質及び TBARS 濃度は共に前者に対し約 $18 \%$ 低下し，また，卵 黄中粗脂肪及び TBARS 含量が低下することも認めら れた。これらの変化は, 飼料摄取量に差がないことから WETによる影響であると考えられる。同時に，WET 0.17\%区における HU の向上が認められた。HU は遺伝 的形質による部分が大きく飼料の影響をほとんど受けな いが (日本飼養標準，1997 年版)，卵重 56.5g 以下の小卵 では卵白高を過大評価しているとの EIsEN et al. (1962) の報告のように, 卵重の減少に伴い高い值を示すことが 知られている。ここでは飼料摂取量, 卵重共に WET 無 添加区と差がないのでこれもWET の影響であると考え る。

本試験のように飼料摂取量に大きな変化が見られる場 合においては，变化の要因を緩和する何らかの方法を考
えて再度確認することが必要であろう。この点について は次の課題としたい。

\section{試験 2}

卵白色の測定結果を表 5 に示した。卵白は通常薄い緑 黄色を呈するが, 試験 1 を終了した段階で WET 添加区 の卵白の緑黄色がほとんど消失することに気付いた。こ のことから卵白色におよぼすWET の影響を明らかにす るため試験 2 を実施した。その結果, WET 添加量が増 すにつれて, 卵白の緑黄色が薄れ, 目視ではWET $0.17 \%$ 以上では卵白の緑黄色が殆ざ消失した。卵白色の 指標とした $440 \mathrm{~nm}$ に招ける吸光度はWET $0.17 \%$ 以上 の添加で無添加区より減少し, 目視での結果を裏付け た。また, この卵白を粯汼, 発泡させると WET 無添加 区に比較し純白度が増加した。この原因については明ら かではない。

なお, 今回使用した茶抽出物は茶葉の温湯抽出物で, カテキン類の他にカフェイン, アミノ酸, 遊離還元糖, 水溶性ペクチンや色素などが含まれている。従って, 本 実験で認められたいくつかの現象の原因を全てカテキン に求めるのは危険である。

\section{引用 文 献}

Asakawa, T. and Matsushita, S. (1980) Coloring Conditions of Thiobarbituric Acid Test for Detectiong Lipid Hydroperoxides. Lipids, 15 : 137-140.

青柳陽介・大西 崇・伊東 忍・中谷哲郎 (1997) 暑熱 ストレス及び L-アスコルビン酸-2-リン酸マグネシウ ムがニワトリヒナの血墏と肝蔵のチオバルビッール酸 反応物および肝臓のタンパク質カルボニル濃度に及ぼ 寸影響. 日本家禽学会誌, 34:63-66.

浅井 肇 - 久納保夫 - 小川晴子 - 原 征彦 - 中村耕三 （1987）自然発症糖尿病マウスにおけるアルミニウ ム・茶カテキン錯体の血糖低下作用. 基礎と臨床, $21: 163-166$.

浅井 肇・山本 肇・原 征彦（1990）茶カテキン錯体 の抗潰瘍作用. 基礎之臨床, 24:177-183.

Duncan, D.B. (1955) Multiple Range and Multiple F Test. Biometrics, 11, 1-42.

Eisen, E.J., Bohren, B.B. and Mckean, H.E. (1962) The Haugh Unit as a Measure of Egg Albumen Quality. Poultry Science, 41, 1461-1468.

Hara, H., Orita, N., Hatano, S., Ichikawa, H., Hara, Y., Matsumoto, N., Kimura, Y., Terada, A. and MitsuoKa, T. (1995) Effect of Tea Polyphenols on Fecal Flora and Fecal Metabolic Products of Pigs. Journal of Veterinary Medical Science, 57, 45-47.

原 征彦・松崎妙子・鈴木達夫（1987）茶成分のアンジ オテンシンI変換酵素阻害能について. 日本農芸化学 会誌, $61: 803-808$.

原 征彦 (1988) 天然物中の抗突然変異因子の検索と同 
定. ファルマシア, $24: 265-270$.

原 征彦・松崎 敏・中村耕三 (1989) 茶カテキンの抗 腫瘍作用. 日本栄養・食糧学会誌, 42:39-45.

原 征彦・外岡史子（1990）茶カテキンのラット血圧上 昇に及ぼす抑制効果. 日本栄養・食糧学会誌, 43 : 345-348.

Hattori, M., Kusumoto, I.T., Namba, T., Ishigami, T. and HARA, Y. (1990) Effect of Tea Polyphenols on Glucan Synthesis by Glucosyltransferase from Streptococcus mutans. Chemical and Pharmaceutical Bulletin, 38, 717-720.

HondA, M. and HARA, Y. (1993) Inhibition of Rat Small Intestinal Sucrase and $\alpha$-Glucosidase Activity by Tea Polyphenols. Bioscience, Biotechnology and Biochemistry, 57, 123-124.

福興真弓・原 征彦・村松敬一郎 (1986) 茶葉力テキン の構成成分である(-)-エピガロカテキンガレートの 血中コレステロール低下作用. 日本栄養・食糧学会 誌, 39 : 496-500.

池ヶ谷賢次郎（1987）茶の製造と栄養成分. 食の科学, $117: 29-35$.

池谷守司・鳥居幸男・佐野満昭・小泉 豊 (1995) 鵎に 対する茶葉の添加が生産性と卵質及び肉質に及ぼす影 響. 静岡県中小家畜試験場研究報告, 8:19-23.

岩田多子・稲山貴代・二輪里見・川口一男（1987）高血 圧自然発症ラット並びに果糖誘導性高脂血症ラットの 血圧, 血漿脂質, 肝臟脂質に及ぼす中国緑茶, ウーロ ン茶の影響. 日本栄養・食糧学会誌, 40:469-477.

Matsumoto, N., Ishigaki, F., Ishigaki, A., Iwashima, H. and HarA, Y. (1993) Reduction of Blood Glucose Levels by Tea Catechin. Bioscience, Biotechnology and Biochemistry, 57, 525-527.

松崎妙子・原 征彦 (1985) 茶葉力テキン類の抗酸化作 用について。日本農芸化学会誌，59：129-134.

Mukoyama, A., Ushijima, H., Nishimura, S., Koike, H., Toda, M., Hara, Y. and Shimamura, T. (1991) Inhibition of Rotavirus and Enterovirus Infections by Tea Extracts. Japanese Journal of Medical Science and Biology, 44, 181-186.

Muramatsu, K., Fukuyo, M. and Hara, Y. (1986) Effect of Green Tea Catechins on Plasma Cholesterol Level in Cholesterol-Fed Rats. Journal of Nutritional Science and Vitaminology, 32, 613-622.

Nakayama, M., Suzuki, K., Toda, M., OKubo, S., Hara, Y. and Shimamura, T. (1993) Inhibition of the Infectivity of Influenza Virus by Tea Polyphenols.
Antiviral Research, 21, 289-299.

NAMIKI, M. and OsAWA, T. (1986) Antioxidants/ Antimutagens in Foods. Basic Life Sciences, 39, 131-142.

Nanjo, F., Honda, M., Okushio, K., Matsumoto, N., IsHIGAKI, F., IsHigAmI, T. and HARA, Y. (1994) Effect of Dietary Tea Catechins on $\alpha$-Tocopherol Levels, Lipid Peroxidation and Erythrocyte Deformability in Rats Fed on High Palm Oil and Perilla Oil Diet. Biological and Pharmaceutical Bulletin, 16, 1156.

日本薬学会編 (1990) 衛生試験法・注解, 340 頁, 金原出 版, 東京.

農林水産省農林水産技術会議事務局編（1997）日本飼養 標準 家禽, 80 頁.

OKuda, T., Yoshida, T., Hatano, T., Kimura, Y., OKuda, H. and ARICHI, S. (1983) Studies on the Activities of Tannins and Related Compounds from Medicinal Plants and Drugs. I. Inhibitory Effect of on Lipid Peroxidation in Mitochondria and Microsomes of Liver. Chemical and Pharmaceutical Bulletin, 31, 1625-1631.

大澤俊彦・並木満夫（1982）脂質の過酸化と変異原性. 変異原と毒性, $5: 243-252$.

佐野満昭 (1995) 茶の家畜飼料への有効利用について. 農業技術研究, 49:64-65.

佐野満昭・佐々木清隆 ·富田 勲・池谷守司・鳥居幸 男・小泉 豊・小泊重洋 (1996) 鶏肉の鮮度保持に及 ぼす茶葉粉末投与の効果. 食品衛生学会誌, $37: 38-$ 42.

戸田真佐子・大久保幸枝・大西玲子 ・島村忠勝（1989） 日本茶の抗菌作用及び殺菌作用について．日本細菌学 雑誌, $44: 669-672$.

戸田真佐子 ·大久保幸枝 ·生見 初 ·島村忠勝（1990） 茶カテキン類及びその構造類似物質の抗菌作用並びに 抗毒素作用. 日本細菌学雑誌, 45:561-566.

Y AGI, K. (1976) A Simple Fluorometric Assay for Lipid Peroxide in Blood Plasma. Biochemical Medicine, 15, 212-216.

安田英之 (1992) 茶カテキン類の消臭作用とその利用. 食品工業, 35, 29-31.

Yoshino, K., HarA, Y., SANO, M. and TomitA, I. (1994) Antioxidative Effects of Black Tea Theaflavins and Thearubigin on Lipid Peroxidation of Rat Liver Homogenates by tert-Butyl Hydroperoxide. Biological and Pharmaceutical Bulletin, 17, 146-149. 


\title{
Effects of Hot Water Extracts of Tea on Performance of Laying Hens
}

\author{
Tetsuo Yamane, Hisaya Goto, Daizo Takahashi, Hidetsugu Takeda, \\ Kenjin Otowaki and Takao Tsuchida \\ Central Laboratory of Nippon Formula Feed Mfg. Co., Ltd. 4-2 Higashifukashiba, \\ Kamisu-machi Kashima-Gun Ibaraki 314-0103, Japan
}

The effects of hot water extract of tea (WET) on serum components, egg production, egg qualities and egg contents of laying hens were examined. Mash feeds $(18.3 \%$ $\mathrm{CP}$ and $2,850 \mathrm{kcal} / \mathrm{kg} \mathrm{ME}$ ) containing 0 to $0.67 \%$ of WET, having $30 \%$ catechins, were given ad libitum to laying hens for 6 weeks from 53 weeks of age.

1. The serum concentration of total lipids tended to decrease, and that of TBARS decreased significantly with increasing dietary WET.

2. Egg production, egg weight and feed intake decreased significantly with increasing dietary WET.

3. Haugh unit was improved about $5 \sim 8 \%$ by the addition of $0.17 \%$ and $0.67 \%$ WET. There were no differences in egg shell thickness nor strength of egg shell among the experimental groups.

4. The contents of crude fat and TBARS in egg yolk decreased about 10 and $16 \%$, respectively, by addition of $0.17 \%$ WET to the diet. TBARS content in crude fat of egg yolk tended to decrease with increasing dietary WET. The fatty acid composition was not affected by the dietary WET levels.

5. The greenish yellow color of egg white disappeared in the groups fed the diet containing $0.17 \%$ or more WET.

(Jpn. Poult. Sci., 36 : 31-37, 1999)

Key words : hot water extract of tea, catechin, crude fat in egg yolk, thoibarbituric acid reactive substances, color of egg white 